Check for updates

Cite this: RSC Adv., 2017, 7, 36492

\title{
Nanomaterials in plant tissue culture: the disclosed and undisclosed
}

\author{
Doo Hwan Kim, Judy Gopal (D) and lyyakkannu Sivanesan*
}

Plant tissue cultures are the core of plant biology, which is important for conservation, mass propagation, genetic manipulation, bioactive compound production and plant improvement. In recent years, the application of nanoparticles (NPs) has successfully led to the elimination of microbial contaminants from explants and demonstrated the positive role of NPs in callus induction, organogenesis, somatic embryogenesis, somaclonal variation, genetic transformation and secondary metabolite production. This review aims to consolidate all of the current achievements made through the integration of nanotechnology into plant tissue culture and highlight the positive attributes of using NPs in plant tissue culture. Both the positive and adverse effects of using NPs in the culture medium are discussed and presented. The toxicity aspects and the safety concerns of exposing plants and the associated environment to NPs are recorded. Finally, future prospects through the involvement of not merely Ag, $\mathrm{TiO}_{2}$, and $\mathrm{ZnO}$ NPs, but more recent innovations such as graphene, carbon nanotubes, $\mathrm{SiO}_{2}$, quantum dots, and dendrimers are proposed. The undisclosed shadows hanging in the background, including the repercussions of using nanomaterials without proper awareness, as well as dosage-based adverse effects and nanotoxicity aspects, are highlighted. The need for more research in the pursuit of discrete answers to unresolved questions regarding mechanisms is emphasized as the key to real progress in plant nanobiotechnology.

Received 24th June 2017 Accepted 13th July 2017

DOI: 10.1039/c7ra07025j

rsc.li/rsc-advances

\section{Introduction}

Plant tissue culture is directed towards the growth of plant cells or parts of plants on a nutrient medium under a controlled, sterile, simulated environment. It is an important technique for both basic and applied areas of plant biology, such as cytology, embryogenesis, morphogenesis, nutrition, pathology and germplasm conservation, genetic manipulation, large-scale clonal propagation, and the production of pathogen-free plants and useful metabolites. ${ }^{1}$ An efficient plant regeneration protocol is mandatory for genetic transformation and mass propagation. The success of in vitro plant culture depends on several factors, such as genotype, the physiological status of the donor plants, the type of explants, surface disinfection methods, the culture medium, plant growth regulators, the size of the culture vessels, spectral quality, light intensity, photoperiod and temperature. ${ }^{2}$ The composition of the culture medium strongly influences the morphogenetic potential of the explants. The medium generally consists of macro- and micronutrients, amino acids, organic supplements, vitamins, carbon sources, plant growth regulators, and solidifying agents. Optimization of the mineral elements in the culture medium

Department of Bioresources and Food Science, Konkuk University, 1, Hwayang-dong, Gwangjin-gu, Seoul 143-701, Republic of Korea. E-mail: isivanesan@gmail.com; Fax: +82 24503310; Tel: +8224500574 enhances the growth and morphogenesis of explants. It also improves cell proliferation, organogenesis, somatic embryogenesis, shoot quality and the bioactive compound content in cell and organ cultures.

We are living in the 'Nano Age', the era when every aspect of life has a touch of nano, be it the cosmetics we use, the textiles we wear, the appliances we use, the gadgets we employ, the food we eat, or the environment we live in; whether we like it or not, nanomaterials are already in us, on us and around us. Nanotechnology involves the study and manipulation of materials at length scales below $100 \mathrm{~nm}$. The visionary who first predicted the nano era was Richard Feynman. In December of 1959, he gave a talk, "There's Plenty of Room at the Bottom" at an annual meeting of the American Physical Society at Caltech. It was in this historical classic lecture that Feynman laid the conceptual foundations for the field now called nanotechnology; this was when he imagined a day when things could be miniaturized. He urged scientists to start looking down to smaller invisible materials for bigger solutions and answers. Today, as it now stands, there is indeed plenty of room at the bottom; nanotechnology has bombarded all walks of life, and every discipline in science, be it biology, chemistry, physics, engineering or medicine. Nanomaterials, including nanoparticles, nanocoatings, nanofilms, nanosheets, and nanoclusters, have delivered what their bulk components had failed to. Today's nanotechnology harnesses progress in chemistry, physics, 
materials science and biotechnology to create novel materials that have unique properties because their structures are determined on the nanometer scale. Some of these materials have already found their way into consumer products, like sunscreens and stain-resistant paints and textiles. Others are being intensively researched for solutions to humanity's greatest problems - diseases, clean energy, clean water and a cleaner environment. Some of the noteworthy applications of nanomaterials include: cosmetics (e.g. sunscreen lotions with radiation absorbing properties); nanocomposite materials and nanotubes as reinforced fillers to improve the mechanical properties of nanocomposites and impart new properties (optical, electronic etc.); nanocoatings, where a nanometer thickness of a nanomaterial can be used to improve properties like wear and scratch-resistance, optoelectronic properties, and hydrophobic properties; hard cutting tools using metal nanocomposites such as tungsten carbide, tantalum carbide and titanium carbide, which have improved wear and erosionresistance, and last longer than their conventional bulk materials; displays, using carbon nanotubes as emission devices for monitors and televisions (FEDs: field-emission displays); lightweight, high-energy density batteries; fuel additives and catalytically efficient materials; nanospheres as lubricants; nanoscale magnetic materials in data storage devices; nanostructured membranes for water purification; and last but not least, inputs into nanoelectronics, nanobiotechnology and nanomedicine..$^{3-9}$

In plant tissue culture, there are numerous reports that indicate positive inputs from nanotechnology. Nanoparticles (NPs) have been widely used to improve seed germination, enhance plant growth and yield, enable plant genetic modification, improve bioactive compound production and achieve plant protection. ${ }^{\mathbf{1 0 , 1 1}}$ On treatment of tomato seeds with silicon dioxide $\left(\mathrm{SiO}_{2}\right)$, the NPs enhanced the percentage of seed germination and seedling growth. ${ }^{12}$ The application of iron and magnesium nano-fertilizers significantly improved the number of seeds per pod and the seed protein content in black-eyed peas. ${ }^{13}$ Au-capped mesoporous silica NPs delivered DNA into the protoplasts, cells and leaves of tobacco. ${ }^{14}$ Treatment of licorice seedlings with copper oxide $(\mathrm{CuO})$ and zinc oxide $(\mathrm{ZnO})$ increased the content of anthocyanins, flavonoids, glycyrrhizin, phenolic compounds and tannins. ${ }^{15}$ Silica-silver NPs were reported to possess antimicrobial activity against several plant pathogens. The application of silica-silver NPs to infected plants of green squash was found to be useful for powdery mildew control. ${ }^{16}$ Recent studies have shown that surface disinfection of explants with NPs significantly reduces microbial contamination in various plants. The addition of NPs to tissue culture media can eliminate bacterial contamination and enhance the morphogenetic potential of explants. The inclusion of NPs in the medium also resulted in somaclonal variation. The treatment of plant cell, tissue or organ cultures with NPs increased their content of bioactive compounds. Engineered NPs have been used to deliver DNA or proteins into plants. Recently, Sarmast and Salehi ${ }^{17}$ reviewed the application of silver NPs in plant tissue culture. It was interesting to observe that although there were scattered reports across plant biotechnology journals on the application of nanomaterials in plant tissue culture, there were no consolidated reviews on this topic. This review summarizes the current achievements regarding the use of NPs in plant tissue culture. The milestones achieved in the elimination of microbial contamination in plant cultures, callus induction, organogenesis, somatic embryogenesis, somaclonal variation, genetic transformation and metabolite production through the introduction of nanomaterials are presented. The need to incorporate more of the new-age nanomaterials, such as graphene and carbon buckyballs, and the possibility of creating nano-environments for effective plant tissue culture are speculated upon in the future prospects section.

\section{Nanotechnological achievements in plant tissue culture (Fig. 1)}

\subsection{Input of nanomaterials for surface disinfection of explants}

Microbial contamination is a serious problem when it comes to plant tissue culture (Fig. 2). Microbial contamination can extinguish the entire process and efficiency of the propagation system even before initialization. The explants themselves and the laboratory environment used are the sources of contaminants. ${ }^{18}$ Usually, the various organs collected from field- or greenhouse-grown plants are surface sterilized before the establishment of in vitro cultures. However, in many instances, this has proved inadequate and hence many experimental set
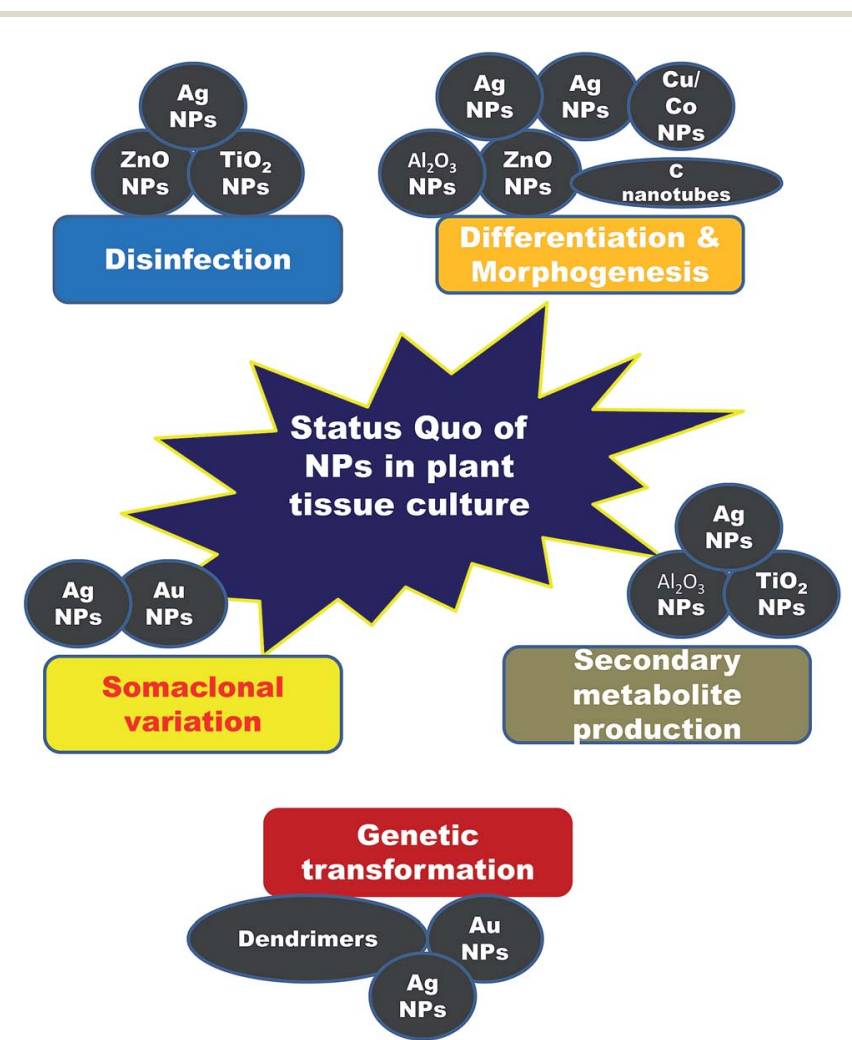

Fig. 1 Schematic showing an overview of the various NPs currently involved in plant tissue culture. 
ups have been ruined, which has led to a loss of labor and time. Surface disinfection of the explants is a major step prior to in vitro culture initiation because microorganisms grow faster in tissue culture medium than the explants do, and they can seriously affect culture initiation. Several sterilizing agents such as bromine water (BW), calcium hypochlorite ( $\mathrm{CaOCl})$, ethanol (EtOH), hydrogen peroxide $\left(\mathrm{H}_{2} \mathrm{O}_{2}\right)$, sodium hypochlorite (NaOC1), mercuric chloride $\left(\mathrm{HgCl}_{2}\right)$, silver nitrate $\left(\mathrm{AgNO}_{3}\right)$, antibiotics, and fungicides are in use to obtain sterile explants. ${ }^{18}$ The concentration of disinfectants and exposure time often affect the quality of the explants. Moreover, eliminating endogenous bacteria is often very challenging and therefore, several antibiotics and $\mathrm{AgNO}_{3}$ are included in the culture medium to kill the bacteria or prevent bacterial growth. ${ }^{19}$ However, the phytotoxicity of antibiotics to cell, tissue and organ cultures of various plant species has also been reported. ${ }^{19-23}$ Some disinfecting agents have even failed to eliminate contaminants in explants, and instead they profoundly affected organogenesis due to their phytotoxicity. Metal and metal oxide NPs have been proven to be useful for the elimination of various microorganisms. ${ }^{24} \mathrm{~A}$ wide range of NPs such as silver $(\mathrm{Ag})$, aluminum oxide $\left(\mathrm{Al}_{2} \mathrm{O}_{3}\right), \mathrm{CuO}$, iron oxide $\left(\mathrm{Fe}_{3} \mathrm{O}_{4}\right)$, gold ( $\mathrm{Au})$, magnesium oxide ( $\mathrm{MgO})$, nickel (Ni), silicon ( $\mathrm{Si}), \mathrm{SiO}_{2}$, titanium dioxide $\left(\mathrm{TiO}_{2}\right)$, and $\mathrm{ZnO}$ have been reported to possess antimicrobial activities against various microorganisms. ${ }^{25} \mathrm{Abdi}$ et $a l .{ }^{26}$ employed Ag NPs for the first time to control bacterial

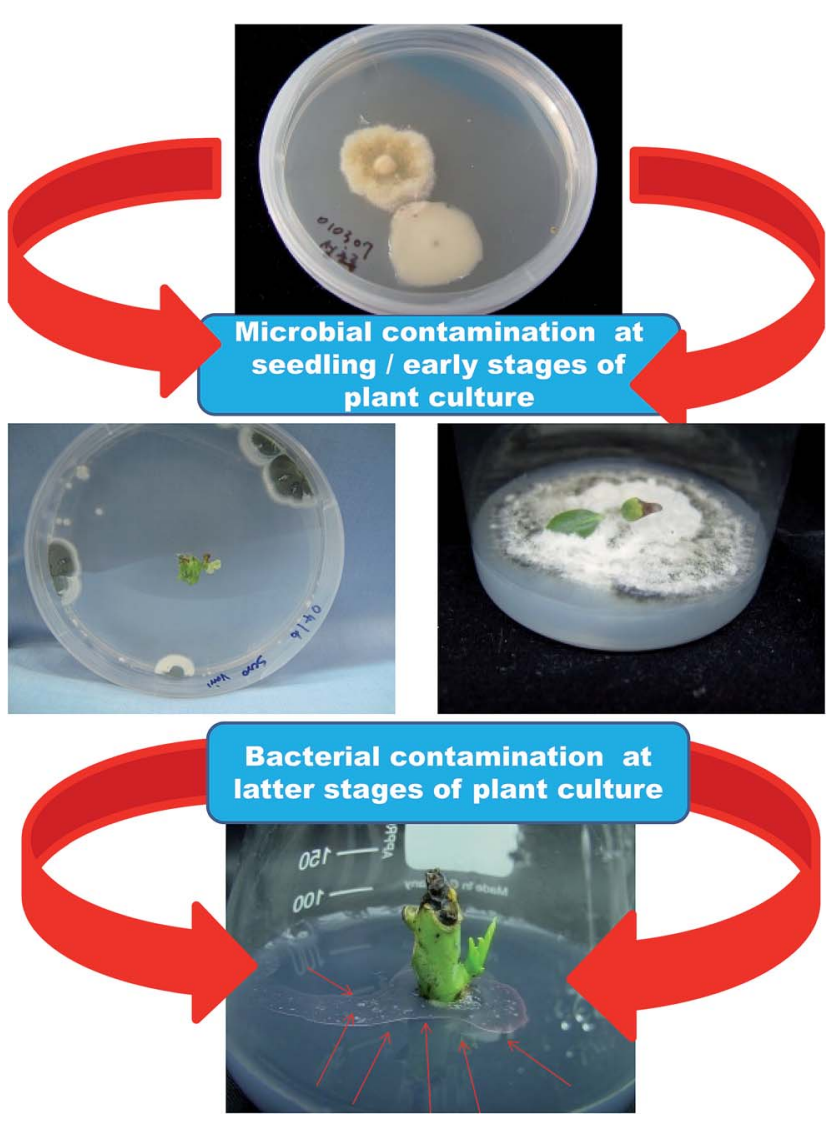

Fig. 2 Slides showing microbial contamination during different phases of the plant culturing process. contamination in Valeriana officinalis. Single node explants obtained from greenhouse-grown plants were surface disinfected with $70 \% \mathrm{EtOH}$ for $1 \mathrm{~min}, 10 \%$ Clorox for $1 \mathrm{~min}$ and then $100 \mathrm{mg} \mathrm{L}^{-1}$ of $\mathrm{Ag}$ NPs for $180 \mathrm{~min}$; this process resulted in $89 \%$ contamination-free cultures. Moreover, the Ag NP treatment did not affect shoot multiplication and subsequent rooting. Similarly, treatment of the immature capitulum of Gerbera jamesonii with $1.5 \% \mathrm{NaOCl}$ for $10 \mathrm{~min}$ and $200 \mathrm{mg} \mathrm{L}^{-1} \mathrm{Ag}$ NPs for $15 \mathrm{~min}$ successfully eliminated all contaminants and showed no adverse effects on organogenesis. ${ }^{27}$ Leaf explants of Vitis vinifera 'Farkhi', 'Khoshnave' and 'Rashe' were successfully decontaminated with $95 \% \mathrm{EtOH}$ for $30 \mathrm{~s}$, and $1000 \mathrm{mg} \mathrm{L}^{-1} \mathrm{Ag}$ NPs for 20 min. $^{28}$

Mahna et al. ${ }^{29}$ investigated the effect of Ag NP treatment on surface disinfection of Arabidopsis seeds, potato leaves and tomato cotyledons. The treatment of the explants with $100 \mathrm{mg}$ $\mathrm{L}^{-1} \mathrm{Ag}$ NPs for 1 or $5 \mathrm{~min}$ was found to be ideal for decontaminating $(100 \%)$ the seeds, leaves or cotyledons and this treatment had no side effects on explant viability. However, seed germination and leaf and cotyledon survival were reduced when they were treated with higher concentrations of Ag NPs. Elimination of microbes from in vitro cultures is a huge challenge when it comes to woody plants. Node and shoot tips obtained from 9 year-old olive plants were treated with $70 \%$ EtOH for $1 \mathrm{~min}$, followed by $10 \%$ Clorox for $10 \mathrm{~min}$, and this yielded $51.4 \%$ contamination-free culture. Treating the explants in $100 \mathrm{mg} \mathrm{L}{ }^{-1} \mathrm{Ag}$ NPs for $60 \mathrm{~min}$ after EtOH and Clorox exposure completely prevented contamination, but only a few explants survived. On the other hand, supplementation of Ag NPs (4 mg $\mathrm{L}^{-1}$ ) to the culture medium adequately controlled internal contaminants in the olive explants and no negative effects were observed on the explants and their growth. ${ }^{30}$ Sarmast et al. ${ }^{31}$ reported that surface sterilization of explants of Araucaria excelsa followed by immersion in $200 \mathrm{mg} \mathrm{\textrm {L } ^ { - 1 }}$ of $\mathrm{Ag}$ NPs for $180 \mathrm{~min}$ reduced the rate of contamination from 61.5 to $11.3 \%$. The inclusion of $400 \mathrm{mg} \mathrm{L} \mathrm{L}^{-1}$ of Ag NPs in the culture medium reduced the contamination from 81.25 to $18.75 \%$ (Table 1). Similarly, the application of 100 and $150 \mathrm{mg} \mathrm{L}^{-1} \mathrm{Ag}$ NPs, through both immersion and addition to the MS medium, significantly reduced internal and external contamination in $\mathrm{G}$ $\times$ N15 (hybrid of almond $\times$ peach) rootstocks. ${ }^{32}$

The addition of $50 \mathrm{mg} \mathrm{L}^{-1} \mathrm{Ag}$ NPs to Murashige and Skoog $\left(\mathrm{MS}^{33}\right)$ medium significantly inhibited microbial growth. ${ }^{34}$ Similarly, contamination-free cultures were observed when surface-disinfected shoot buds obtained from potato and tobacco were cultured on MS medium supplemented with $\mathrm{Ag}$ NPs or $\mathrm{TiO}_{2} \mathrm{NPs}^{35,36}$ Ideal results were attained on MS medium containing $1 \%(\mathrm{w} / \mathrm{w}) \mathrm{TiO}_{2} \mathrm{NPs}^{37}$ Bacterial contamination was notably reduced when Rosa hybrida explants were treated with $200 \mathrm{mg} \mathrm{L}{ }^{-1} \mathrm{Ag} \mathrm{NP}$ solution for $20 \mathrm{~min}$. On the other hand, the supplementation of $100 \mathrm{mg} \mathrm{L}^{-1}$ AgNPs to the medium reduced the rate of bacterial contamination and also phenolic exudation. ${ }^{38}$ It has been reported that internal bacterial contamination in callus cultures of Bacopa monnieri was significantly reduced by the addition of $160 \mathrm{mg} \mathrm{L}^{-1} \mathrm{Ag}$ NPs to the MS medium. ${ }^{39}$ The addition of $60 \mu \mathrm{g} \mathrm{mL}^{-1} \mathrm{TiO}_{2} \mathrm{NPs}$ to the MS medium eliminated bacterial contamination in callus cultures 


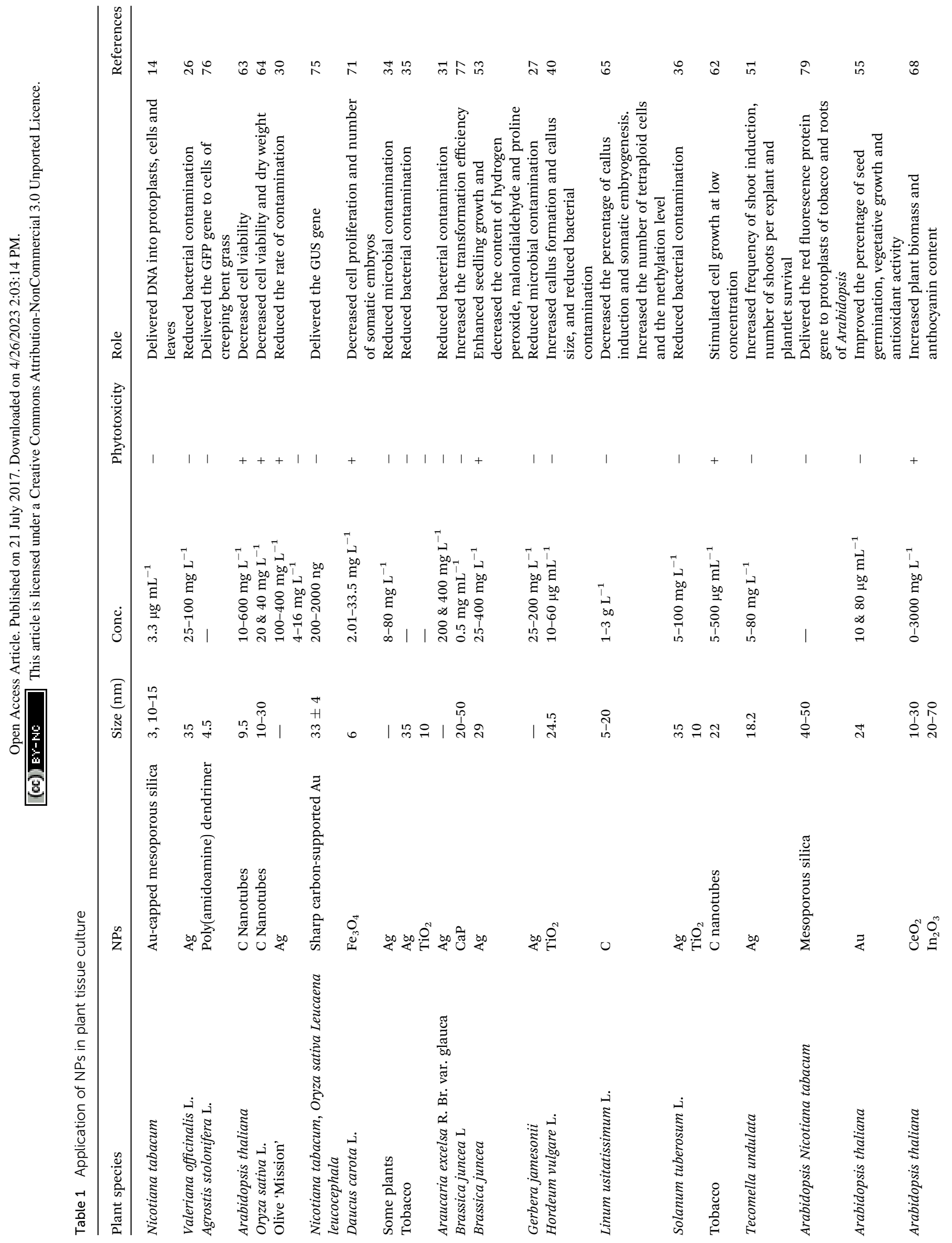




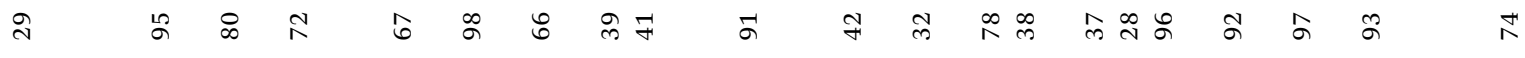

\section{要}

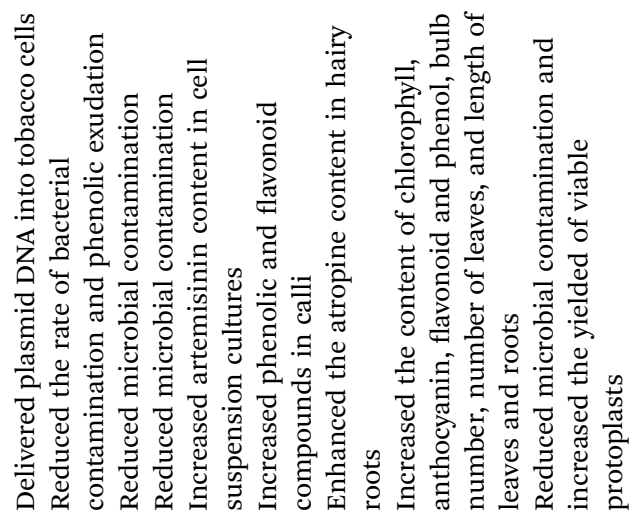

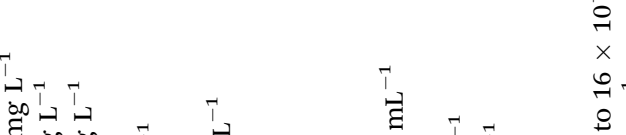

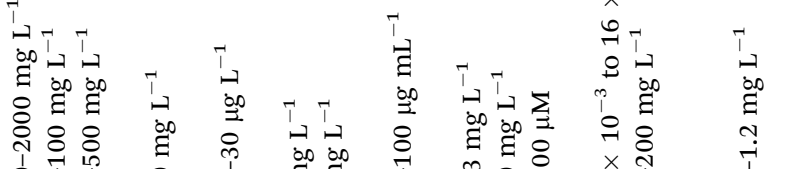

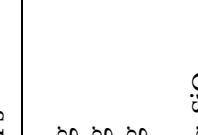

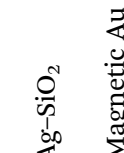

蒁

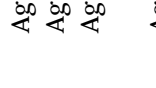

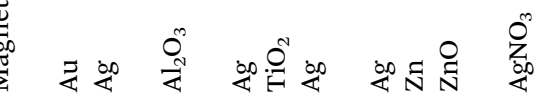

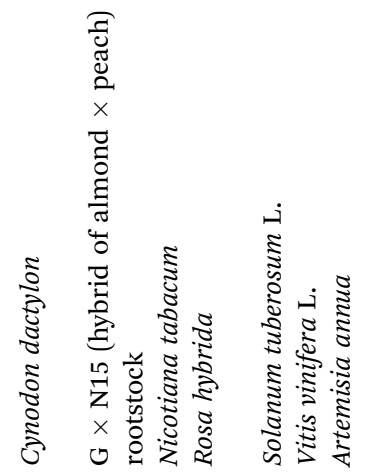




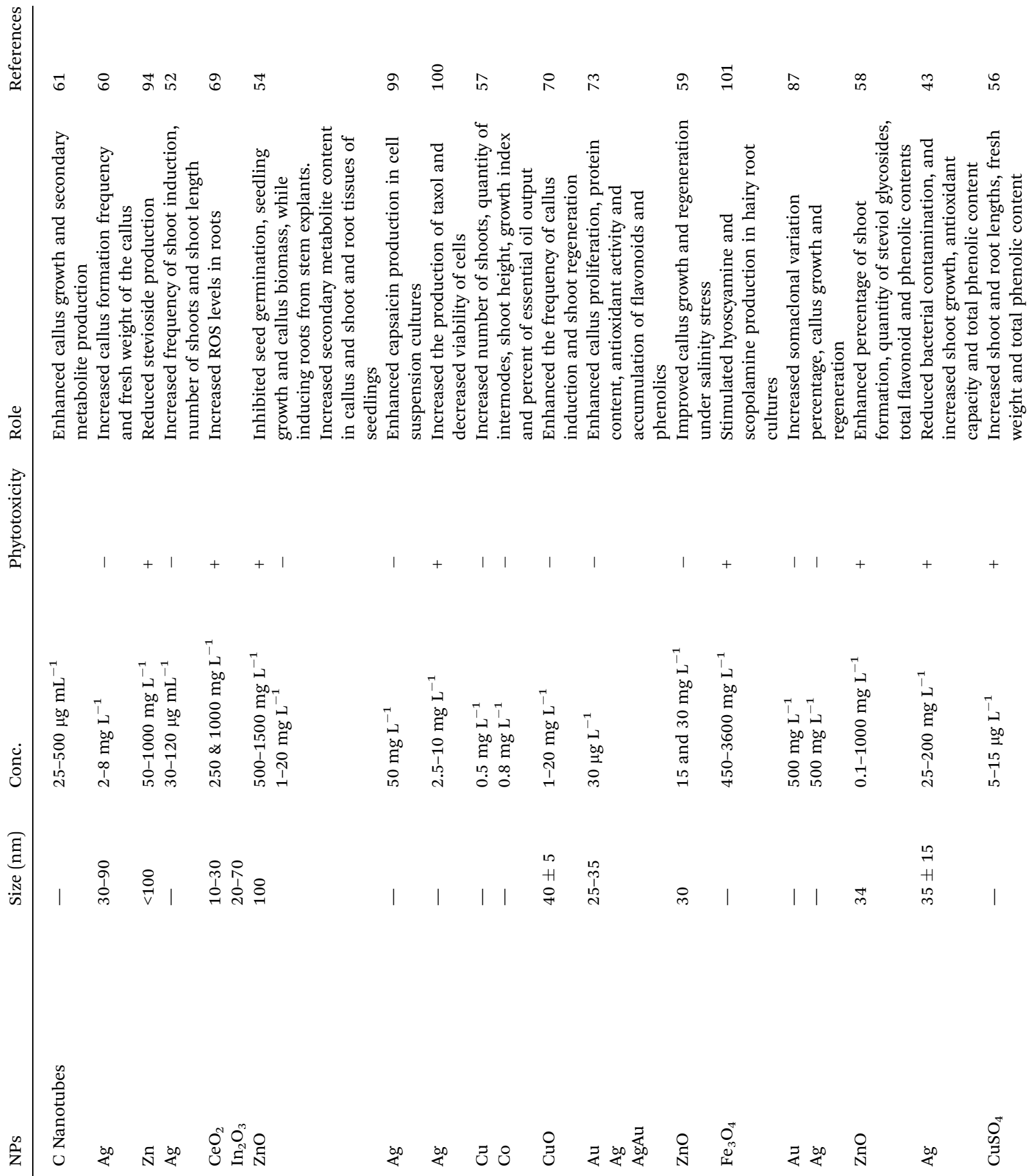

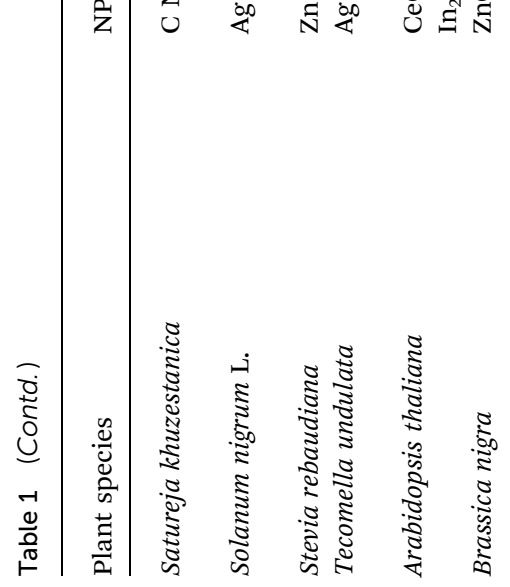

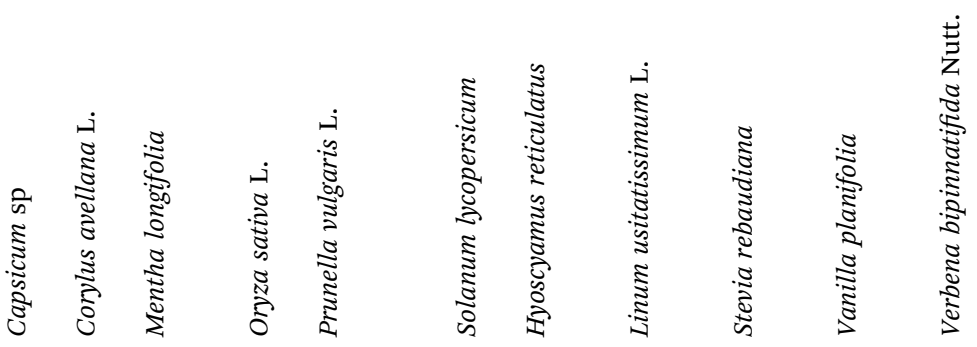


of barley after the $4^{\text {th }}$ subculture. ${ }^{40}$ Helaly et $a l .{ }^{41}$ reported that shoot tips obtained from 3 year-old banana suckers when surface-sterilized with $80 \% \mathrm{NaOCl}, 95 \% \mathrm{EtOH}$ and finally $0.1 \%$ $\mathrm{HgCl}_{2}$ for 15 min failed to eliminate microbial contamination. The authors identified nine strains of bacterial contaminants in the in vitro cultures (Table 1). The incorporation of $100 \mathrm{mg} \mathrm{L}^{-1}$ Zn NPs or ZnO NPs into the MS medium resulted in contamination-free cultures. Taghizadeh and Solgi ${ }^{42}$ reported that a combination of $\mathrm{Ag}$ NPs and thymol inhibited microbial growth in Cynodon dactylon. Contamination-free cultures were established by treating nodal explants with $200 \mathrm{mg} \mathrm{L}^{-1} \mathrm{Ag}$ NP solution containing $100 \mathrm{mg} \mathrm{\textrm {L } ^ { - 1 }}$ thymol for $60 \mathrm{~min}$. SpinosoCastillo et al. ${ }^{43}$ reported that zero contamination was observed in shoot cultures of Vanilla planifolia when MS medium was fortified with 50-200 $\mathrm{mg} \mathrm{L}^{-1} \mathrm{Ag}$ NPs (Fig. 3).

The antibacterial property of NPs is no new theme; it is one of the most established and well-studied achievements of NPs, with the most renowned being $\mathrm{Ag} \mathrm{NPs}^{-\mathrm{TiO}_{2}} \mathrm{NPs}$ and $\mathrm{ZnO}$ NPs. ${ }^{40-50}$ The effectiveness of NPs in the elimination of microbial contaminants in plant tissue cultures depends on their dimensions, size, distribution, and type. Several researchers have reported the survival and subsequent regeneration of explants that were affected negatively by NPs during application periods. Therefore, the effects of different types and levels of NPs on explants obtained from various plant species should be investigated in order to determine the best dose with no or minimal phytotoxicity. The effectiveness of NPs can also be improved by synergistic effects when they are combined with sterilizing agents or antibiotics.

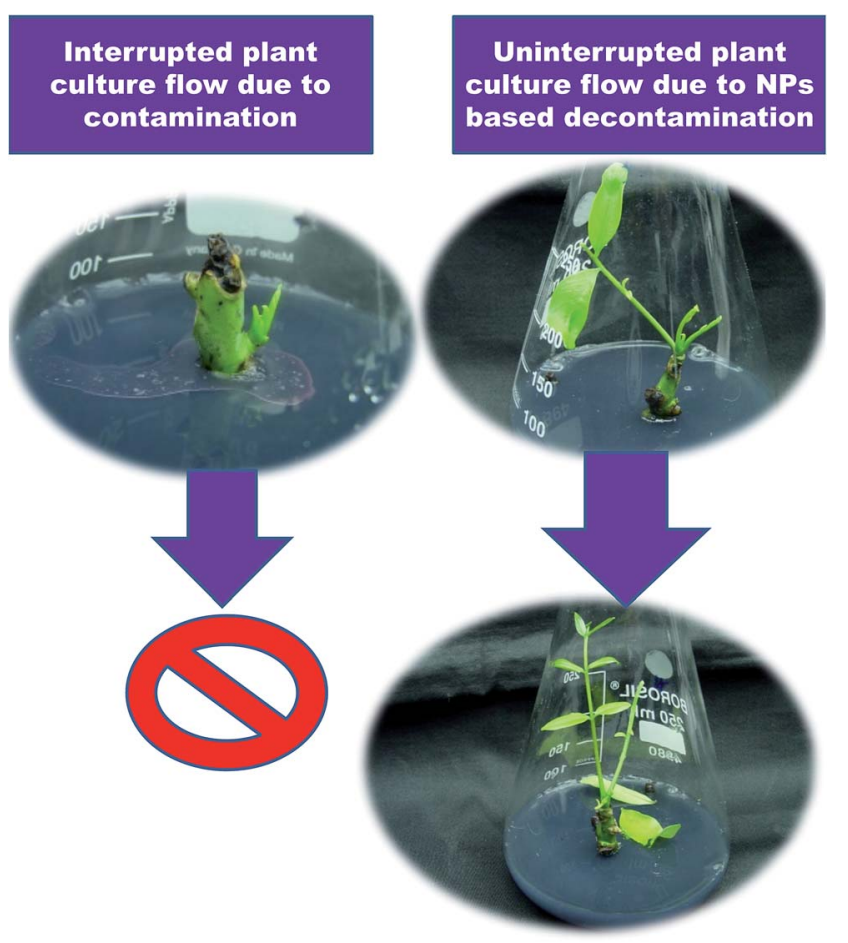

Fig. 3 A smooth and uninterrupted tissue culture process through integration of NPs into the medium for disinfection.

\subsection{Input of nanomaterials towards callus induction, organogenesis, shoot growth and rooting}

Several studies have shown positive effects of NPs on callus induction, shoot regeneration and growth. In Tecomella undulata, the shoot induction percentage, number of shoots and callus formation were increased when the stem explants were cultured on MS medium augmented with $10 \mathrm{mg} \mathrm{L}^{-1} \mathrm{Ag}$ NPs, $2.5 \mathrm{mg} \mathrm{L}^{-1}$ BAP and $0.1 \mathrm{mg} \mathrm{L}^{-1} \mathrm{IAA}^{.1}$ The positive effects of Ag NPs on organogenesis may be due to inhibition of ethylene production. Shoot number, length of induced shoots and percentage of produced shoots were significantly enhanced when nodal explants of $T$. undulata were cultured on MS medium fortified with $60 \mathrm{mg} \mathrm{L}^{-1} \mathrm{Ag}$ NPs, $2.5 \mathrm{mg} \mathrm{L}{ }^{-1}$ BAP and $0.1 \mathrm{mg} \mathrm{\textrm {L } ^ { - 1 }}$ IAA. $^{52}$ Also, Ag NP treatment delayed explant senescence and increased survival by downregulation of the TuACS gene. However, at higher concentrations (above $60 \mathrm{mg}$ $\mathrm{L}^{-1}$ ) a detrimental effect on shoot regeneration was evident. Sharma et al..$^{53}$ reported that incorporation of Ag NPs at $50 \mathrm{mg}$ $\mathrm{L}^{-1}$ into MS basal medium improved the growth characteristics of Brassica juncea seedlings by decreasing the content of hydrogen peroxide, malondialdehyde (MDA) and proline through activating antioxidant enzymes. However, higher concentrations of Ag NPs (100-400 $\left.\mathrm{mg} \mathrm{L}^{-1}\right)$ had a detrimental effect on seedling growth. In Brassica nigra, adding ZnO NPs (500-1500 $\mathrm{mg} \mathrm{L}^{-1}$ ) to the MS medium significantly inhibited seed germination. In the presence of ZnO NPs, the shoot and root lengths were significantly affected. On the other hand, growth of stem explants of $B$. nigra on MS medium containing $1-20 \mathrm{mg} \mathrm{L}^{-1}$ ZnO NPs resulted in root formation. ${ }^{54}$ Kumar et al. ${ }^{55}$ reported that the incorporation of Au NPs into MS basal medium improved the percentage of seed germination and seedling growth in Arabidopsis thaliana. Pod length and number of seeds were higher in plants treated with $10 \mu \mathrm{g} \mathrm{mL}^{-1} \mathrm{Au}$ NPs. The treatment with $\mathrm{Au}$ NPs improved the antioxidant enzyme activity and led to a decrease in the expression of microRNAs (miR398 and miR408) in A. thaliana. These physiological and molecular variations might be responsible for the beneficial effects of Au NPs. The inclusion of $5 \mu \mathrm{g} \mathrm{L}^{-1}$ copper sulfate $\left(\mathrm{CuSO}_{4}\right)$ NPs into the MS medium significantly increased the shoot length $(52 \%$ over control), root length (21\% over control) and fresh weight $(39 \%$ over control) of Verbena bipinnatifida seedlings. ${ }^{56}$ The addition of $0.5 \mathrm{mg} \mathrm{\textrm {L } ^ { - 1 }} \mathrm{Cu}$ NPs and $0.8 \mathrm{mg} \mathrm{L}^{-1}$ Co NPs to modified MS medium increased the number of shoots, shoot length and rooting in Mentha longifolia. ${ }^{57}$ The highest frequency of shoot formation (89.6\%) was obtained when nodal explants of Stevia rebaudiana were cultured on MS medium amended with $1 \mathrm{mg} \mathrm{L}^{-1}$ ZnO NPs. ${ }^{58}$ Spinoso-Castillo et al. ${ }^{43}$ investigated the hormetic effects of Ag NPs (Argovit, a commercial product) on shoot regeneration of Vanilla planifolia using a temporary immersion bioreactor system. The highest number of shoots was obtained on MS medium supplemented with 25 or $50 \mathrm{mg} \mathrm{L}^{-1} \mathrm{Ag}$ NPs, with values of 14.33 and 14.89 , respectively, whereas the lowest number of shoots (4.55) were observed on MS medium supplemented with $200 \mathrm{mg} \mathrm{L}^{-1}$ of Ag NPs.

In tomato plants, callus growth and plant regeneration were maximized on medium containing $15 \mathrm{mg} \mathrm{L}^{-1} \mathrm{ZnO}$ NPs and $3.0 \mathrm{~g}$ 
$\mathrm{L}^{-1} \mathrm{NaCl}^{59} \mathrm{ZnO}$ NPs mitigated the effects of $\mathrm{NaCl}$ by upregulating antioxidant enzymes like GPX and SOD. In Solanum nigrum, the frequency of callus formation (89\%) and the fresh weight of the callus (4.67 $\mathrm{g}$ per leaf explant) were increased on MS medium augmented with $5 \mathrm{mg} \mathrm{L}^{-1} \mathrm{BA}, 3 \mathrm{mg} \mathrm{\textrm {L } ^ { - 1 }} \mathrm{NAA}$ and $8 \mathrm{mg} \mathrm{L}{ }^{-1} \mathrm{Ag}$ NPs. ${ }^{60}$ Ghorbanpour and Hadian ${ }^{61}$ investigated the effect of multi-walled carbon nanotubes $\left(25-500 \mu \mathrm{g} \mathrm{mL}{ }^{-1}\right)$ on callus induction from leaf explants of Satureja khuzestanica. Callus growth improved significantly on B5 medium augmented with $25-50 \mu \mathrm{g} \mathrm{mL}{ }^{-1}$. However, the presence of multi-walled carbon nanotubes at $100-500 \mu \mathrm{g} \mathrm{mL}{ }^{-1}$ decreased the callus biomass. Khodakovskaya et al. ${ }^{62}$ reported that the incorporation of $100 \mu \mathrm{g} \mathrm{mL} \mathrm{m}^{-1}$ multi-walled carbon nanotubes to a medium containing $1 \mathrm{mg} \mathrm{\textrm {L } ^ { - 1 }}$ 2,4-D increased the callus growth of tobacco explants (64\% increase over control). The treatment with carbon nanotubes enhanced callus growth by upregulation of the genes involved in cell division $(C y c B)$, cell wall extension (NtLRX1) and water transport (NtPIP1). However, carbon nanotube treatment (10-600 $\left.\mathrm{mg} \mathrm{L}^{-1}\right)$ decreased cell viability and dry weight in Arabidopsis. ${ }^{63}$ Similarly, the addition of carbon nanotubes to rice cell suspension cultures decreased cell viability. ${ }^{64}$ The presence of carbon NPs in the MS medium reduced the frequency of callus induction in Linum usitatissimum. ${ }^{65}$ Syu et al. ${ }^{66}$ investigated the effects of three different morphologies of Ag NPs, including decahedral (45 $\pm 5 \mathrm{~nm}$ ), spherical $(8 \pm 2 \mathrm{~nm})$ and triangular $(47 \pm 7 \mathrm{~nm})$, on seedling growth, gene expression and physiological changes in Arabidopsis (Table 1). Root growth was enhanced when the seedlings were treated with either triangular or decahedral Ag NPs, whereas it was unaffected following spherical Ag NP treatment. $\mathrm{Ag}$ NP treatment was reported to alter the content of antioxidant enzymes and expression of genes that are involved in the biosynthesis of auxin, abscisic acid and ethylene.

Poborilova et al. $^{67}$ reported that the addition of $\mathrm{Al}_{2} \mathrm{O}_{3}$ NPs (10-100 $\mu \mathrm{g} \mathrm{mL}^{-1}$ ) to tobacco cell suspension cultures significantly decreased cell viability through the generation of reactive oxygen (ROS) and nitrogen species (RNS). The presence of $250 \mathrm{mg} \mathrm{L}{ }^{-1}$ cerium oxide $\left(\mathrm{CeO}_{2}\right)$ and $50-500 \mathrm{mg} \mathrm{L}{ }^{-1}$ indium oxide $\left(\mathrm{In}_{2} \mathrm{O}_{3}\right)$ in half-strength $\mathrm{MS}$ medium significantly increased the biomass of Arabidopsis thaliana seedlings. ${ }^{68}$ However, seedling growth decreased at higher concentrations. ROS production significantly increased when seedlings were exposed to $250 \mathrm{mg} \mathrm{L}^{-1} \mathrm{CeO}_{2}$ and $1000 \mathrm{mg} \mathrm{L}^{-1} \mathrm{In}_{2} \mathrm{O}_{3}$, demonstrating clear oxidative stress in Arabidopsis. ${ }^{69}$ In banana explants, the maximum frequency of somatic embryogenesis was observed in MS medium augmented with $100 \mathrm{mg} \mathrm{L}^{-1} \mathrm{Zn}$ NPs followed by ZnO NPs. Shoot and root lengths were also increased when adding both NPs to the MS medium. ${ }^{41}$ However, higher concentrations decreased the callus growth and enhanced antioxidant enzyme activity. Anwaar et al. ${ }^{70}$ reported that supplementation with CuO NPs (15-20 mg L $\left.{ }^{-1}\right)$ increased organogenesis in rice cultivars. In Daucus carota, cell proliferation and the number of somatic embryos decreased on MS medium containing $\mathrm{Fe}_{3} \mathrm{O}_{4} \cdot{ }^{71}$ It has been reported that $\mathrm{TiO}_{2} \mathrm{NPS}$ may play a role similar to plant growth regulators (PGRs) like cytokinin and gibberellic acid. ${ }^{40}$ The number and size of calli increased when barley mature embryos were grown in MS medium augmented with $20 \mathrm{mg} \mathrm{L}^{-1} 2,4-\mathrm{D}$ and $60 \mu \mathrm{g} \mathrm{mL}{ }^{-1} \mathrm{TiO}_{2}$ NPs. Kokina et al. ${ }^{72}$ prepared a BAP (cytokinin) powder coated with $\mathrm{Au}$ and $\mathrm{Ag}$ NPs and added it to the tissue culture medium. Stem segments of Linum usitatissimum were cultured on MS medium augmented with $1 \mathrm{mg} \mathrm{L}^{-1} 2,4-\mathrm{D}$ plus $1 \mathrm{mg} \mathrm{L}^{-1}$ BAP or $1 \mathrm{mg} \mathrm{L}^{-1} \mathrm{Au}$ BAP or Ag BAP. The inclusion of Au NPs and Ag NPs in the MS medium increased embryogenesis (70\% and $50 \%$, respectively). The authors confirmed deposition of NPs in the cells and hypothesized that the plants actively take up the plant growth regulators (PGRs) and the metal NPs are transported along with the PGRs. However, the actual mechanism via which $\mathrm{Au}$ NPs enhance embryogenesis is still unclear and needs further investigation. Fazal et al..$^{73}$ studied the effects of $\mathrm{Au}$ and Ag NPs individually or in combination on callus proliferation in Prunella vulgaris. The Ag $\left(30 \mu \mathrm{g} \mathrm{L}^{-1}\right), \mathrm{Ag}-\mathrm{Au}(1: 2)$, and $\mathrm{Ag}-\mathrm{Au}$ $(2: 1)$ NPs in combination with NAA $\left(2.0 \mathrm{mg} \mathrm{L}^{-1}\right)$ enhanced callus proliferation $(100 \%)$ compared to the control $(95 \%)$. The highest biomass was obtained when the culture medium was augmented with Au NPs (Table 1).

Hence, from all of these reports it can be concluded that the addition of NPs to a plant tissue culture medium affects callus proliferation, shoot multiplication, somatic embryogenesis and rooting by altering antioxidant enzyme activities, gene expression, inhibition of ethylene production and production of ROS. However, the actual mechanisms of the promotive or inhibitory effects of NPs on each parameter need to be investigated in detail. The effects of various metal and metal oxide NPs on plants are well documented in vivo; such NPs can be used to promote or improve the morphogenetic potential of explants obtained from different plant species. The influence of different concentrations and combinations of NPs on various media (shoot induction, shoot multiplication and rooting media) also deserves evaluation, in order to gain a clear understanding of the underlying mechanisms behind the role of NPs in plant tissue culture.

\subsection{Effect of nanomaterials on genetic transformation}

Electroporation and particle bombardment (direct) and Agrobacterium-mediated (indirect) transformation methods are used for delivering a foreign gene into plant cells, tissues and organs. The electroporation technique has been widely used for transferring genes into protoplasts. However, the isolation and regeneration of protoplasts is not that easy. Bansod et al. ${ }^{74}$ reported that the incorporation of $10 \mathrm{mg} \mathrm{L}^{-1} \mathrm{Ag}$ NPs into the leaf incubation buffer enhanced the viable protoplast yield in tobacco. This is helpful in minimizing the damage caused by cellulolytic enzymes during protoplast isolation and improved costs (which is yet another constraint in protoplast isolation). Torney et al. ${ }^{14}$ demonstrated that mesoporous silica NPs could be used to deliver DNA into tobacco protoplasts by endocytosis; the gold-capped mesoporous silica NPs, DNA and chemicals were delivered into the callus and leaves using a biolistic gun. Vijayakumar et $a .^{75}$ showed that carbon-supported Au NPs delivered DNA more efficiently into Nicotiana tabacum, Oryza sativa and Leucaena leucocephala compared to regular gold particles using a gene gun. The amounts of gold and plasmid 
present in the carbon-supported Au NPs were 4 and 3 times lower, respectively, compared to the commercial micrometersized gold particles. In addition, plant cell damage is minimal and therefore plant regeneration and the transformation frequency is increased. In Agrobacterium-mediated transformation, antibiotics such as carbenicillin, cefotaxime, rifampicin and thimentin have been used for the removal of bacteria after co-cultivation; however, their phytotoxic effects on explants affected the regeneration potential and genetic stability of the regenerated plantlets. Sarmast and Salehi ${ }^{17}$ reported that the growth of A. rhizogenes and A. tumefaciens was completely suppressed on LB medium containing $10 \mu \mathrm{g} \mathrm{mL}$ $\mathrm{Ag}$ NPs. The authors also demonstrated that addition of Ag NPs to the culture medium successfully eliminated bacteria after cocultivation during the Agrobacterium-mediated genetic transformation of T. undulata and tobacco. Other NPs require further testing in order to provide evidence for them eliminating Agrobacterium in the cells, tissues and organs of various plants following co-cultivation.

Pasupathy et al. $^{76}$ developed a novel gene delivery method in plants by using poly(amidoamine) dendrimer NPs. The authors successfully delivered green-fluorescent protein (GFP)-encoding plasmid DNA into turf-grass cells. The transfection efficiency was further enhanced by optimizing the $\mathrm{pH}$ of the culture medium and the molar ratio of the dendrimer to plasmid DNA. Naqvi et al. ${ }^{77}$ used calcium phosphate (CaP) NPs for delivering pCambia 1301 harboring the GUS gene into Brassica juncea. The best transformation efficiency was observed with CaP NPs (80.7\%) followed by Agrobacterium tumefaciens $(54.4 \%)$ and naked DNA (8\%). Recently, Ardekani et al. ${ }^{78}$ reported that $\mathrm{CaP}$ NPs delivered pBI121 harboring the GFP gene into tobacco cells (Table 1). Mesoporous silica NPs have been used for delivering plasmid DNA into tobacco protoplasts and intact Arabidopsis roots. ${ }^{79}$ Magnetic Au NPs can deliver plasmid DNA into the cells and protoplasts of canola and carrot plants. ${ }^{80} \mathrm{NP}$-mediated gene delivery in plants has great importance in plant nanobiotechnology. Further research is warranted to study the effects of different NPs on genetic manipulation of various plant species.

\subsection{Influence of nanomaterials on somaclonal variation}

Changes observed in in vitro developed organs and plantlets are termed somaclonal variation. It is usually associated with changes in chromosome number, chromosome structure, DNA sequence, DNA methylation, mitotic crossing over and activation of transposable elements. ${ }^{\mathbf{8 1 , 8 2}}$ Somaclonal variation has both advantages as well as disadvantages in plant tissue culture. Variants possess several useful characteristics like plant size, flower color, leaf variegation, fruit ripening, secondary metabolite production and resistance to biotic and abiotic stresses. ${ }^{\mathbf{8 3}}$ Several studies have demonstrated the phytotoxicity of NPs primarily applied at higher levels. NP treatments affect the mitotic index and DNA integrity, and alter the protein and DNA expression in plants. ${ }^{\mathbf{8 4 - 8 6}}$ The ploidy level in $L$. usitatissimum calli was significantly affected on MS medium containing C NPs. ${ }^{65}$ The supplementation of C NPs enhanced the number of tetraploid cells. The level of DNA methylation was also higher in calli grown on medium with C NPs. Kokina et al. ${ }^{87}$ investigated the effects of $\mathrm{Au}$ and $\mathrm{Ag}$ NPs on somaclonal variation in L. usitatissimum. The occurrence of somaclonal variation was higher in both calli and regenerated shoots grown on medium containing $\mathrm{Au}$ NPs than Ag NPs. Ewais et al. ${ }^{60}$ reported that the addition of $\mathrm{Ag}$ NPs to tissue culture medium induces variation in callus morphology and anatomy by altering the protein and DNA profile in Solanum nigrum calli (Table 1). Further investigations are required in order to determine the effects of a wide range of NPs for enhancing somaclonal variation.

\subsection{Nanomaterial enhancement of secondary metabolites}

Plants are a rich source of various bioactive secondary metabolites, which play a significant role in the survival of plants in their respective environments. In vitro plant cell and organ culture has been proven to be advantageous for the production of secondary metabolites. The content of secondary compounds in cell and organ cultures was significantly enhanced by optimizing the composition of the culture medium, incorporation of precursors and elicitors and providing appropriate culture conditions. ${ }^{\mathbf{8 3 , 8 8 - 9 0}}$ NPs added to the plant in vitro culture medium may act as a nutrient source and an elicitor. Poborilova et al. ${ }^{67}$ reported that the addition of $\mathrm{Al}_{2} \mathrm{O}_{3}$ NPs $\left(10-100 \mu \mathrm{g} \mathrm{mL}{ }^{-1}\right)$ to tobacco cell suspension cultures significantly increased the phenolic content. The accumulation of phenolics in the cells was dose- and exposure time-dependent. Mohammed Aloubaidi and Mohammed-Ameen ${ }^{91}$ reported that the essential oil content in Calendula officinalis calli was greatly enhanced in MS medium amended with $0.3 \mathrm{mg} \mathrm{L}{ }^{-1} \mathrm{Ag}$ NPs. The presence of $\mathrm{TiO}_{2}$ NPs ( 4.5 or $6.0 \mathrm{mg} \mathrm{L}^{-1}$ ) significantly increased the content of gallic acid, chlorogenic acid, $o$-coumaric acid, tannic acid and cinnamic acid in embryonic calli of Cicer arietinum. ${ }^{92}$ The application of $\mathrm{Au}-\mathrm{Ag}$ NPs $(1: 3)$ induced maximum accumulation of total phenolic compounds and flavonoids in callus cultures of Prunella vulgaris. ${ }^{73}$ Syu et al. ${ }^{66}$ reported that the shape of Ag NPs plays a significant role in the production of anthocyanins in Arabidopsis. Treatment with spherical Ag NPs resulted in the highest levels of anthocyanin accumulation in seedlings. Vanilla planifolia shoots grown in MS medium supplemented with 25 and $50 \mathrm{mg} \mathrm{L}^{-1} \mathrm{Ag}$ NPs showed a significant increase in total phenolic content. ${ }^{43}$ Chamani et al. ${ }^{93}$ reported the accumulation of specific bioactive compounds in Lilium ledebourii and its dependency on the concentration of ZnO NPs in the MS medium. The highest content of flavonoids, phenolics and anthocyanins was obtained on MS medium supplemented with 25, 75 and $100 \mathrm{mg} \mathrm{L}^{-1} \mathrm{ZnO}$ NPs, respectively. The accumulation of steviol glycosides in shoot cultures of $S$. rebaudiana was significantly enhanced on MS medium fortified with $1 \mathrm{mg} \mathrm{\textrm {L } ^ { - 1 }} \mathrm{ZnO}^{58}$ In addition, the total flavonoid and phenolic content also increased with $\mathrm{ZnO}$ treatment. However, higher concentrations of $\mathrm{ZnO}$ led to decreased secondary metabolite production due to the phytotoxic effects of $\mathrm{ZnO}$. Desai et al. ${ }^{94}$ reported that the addition of $50-1000 \mathrm{mg} \mathrm{L}^{-1} \mathrm{Zn}$ NPs decreased the production of stevioside in shoot cultures of $S$. rebaudiana (Table 1). The content of total phenolics in the 
seedlings of Verbena bipinnatifida was enhanced two-fold when they were grown on MS medium containing $5 \mu \mathrm{M} \mathrm{CuSO}_{4} \mathrm{NPs}^{56}$ Application of $\mathrm{Cu}$ and $\mathrm{Co}$ NPs increased the essential oil content in Mentha longifolia by 2.226 and $2.19 \%$, respectively. ${ }^{57}$ In $S$. khuzestanica leaf cultures, the incorporation of multi-walled carbon nanotubes in B5 medium (25 or $50 \mu \mathrm{g} \mathrm{mL}{ }^{-1}$ ) gave maximum callus growth, while the highest content of phenolics, flavonoids, rosmarinic acid and caffeic acid was obtained on B5 medium with 100 or $250 \mu \mathrm{g} \mathrm{mL}{ }^{-1}$ multi-walled carbon nanotubes. ${ }^{61}$

Zhang et $a l .{ }^{95}$ investigated the elicitation potential of Ag NPs on increasing the content of artemisinin in hairy root cultures of Artemisia annua. The production of artemisinin showed a 3.9fold increase when the cultures were treated with $900 \mathrm{mg} \mathrm{L}^{-1} \mathrm{Ag}$ NPs for 3 days. Similarly, the highest artemisinin content (2.2fold increase over the control) was obtained in cell suspension cultures of $A$. annua $24 \mathrm{~h}$ after treatment with $5 \mathrm{mg} \mathrm{L}^{-1}$ Co NPs. ${ }^{96}$ The authors concluded that the Co NP treatment increased the artemisinin content as a result of downregulation of the SQS and DBR2 genes. Shakeran et al. ${ }^{97}$ investigated the effects of biotic (Bacillus cereus and Staphylococcus aureus) and abiotic $\left(\mathrm{AgNO}_{3}\right.$ and $\left.\mathrm{Ag} \mathrm{NPs}\right)$ elicitors on atropine production in hairy root cultures of Datura metel. Hairy root cultures were exposed to elicitors for 12, 24 and $48 \mathrm{~h}$. Among the studied elicitors, Ag NPs were the most effective in enhancing the content of atropine in hairy roots. Raei et al. ${ }^{98}$ reported that Aloe vera suspension cells interacting with $0.625 \mathrm{mg} \mathrm{L}^{-1} \mathrm{Ag}$ NPs or $120 \mathrm{mg} \mathrm{L}^{-1}$ $\mathrm{TiO}_{2}$ NPs for $48 \mathrm{~h}$ exhibited a significantly increased aloin content. The highest content of aloin was obtained subsequent to $\mathrm{TiO}_{2} \mathrm{NP}$ treatment. Bhat and Bhat ${ }^{99}$ reported that addition of $\mathrm{Ag}$ NPs at $3 \mathrm{mg} \mathrm{\textrm {L } ^ { - 1 }}$ to a Capsicum frutescens cell suspension increased the content of capsaicin about 2-fold. Treatment of a Corylus avellana cell suspension culture with $5 \mathrm{mg} \mathrm{L}^{-1} \mathrm{Ag}$ NPs significantly increased the production of taxol. However, treatment with 2.5 and $10 \mathrm{mg} \mathrm{\textrm {L } ^ { - 1 }} \mathrm{Ag}$ NPs reduced the taxol production potential of the cells to 60 and $56 \%$ of the control, respectively. ${ }^{100}$ Moharrami et $a l .{ }^{101}$ investigated the elicitation potential of Fe NPs (450-3600 $\left.\mathrm{mg} \mathrm{L}^{-1}\right)$ for increasing the content of hyoscyamine and scopolamine in hairy root cultures of Hyoscyamus reticulatus. The exposure of hairy root cultures to $900 \mathrm{mg} \mathrm{L}{ }^{-1}$ Fe NPs for $24 \mathrm{~h}$ and $450 \mathrm{mg} \mathrm{L}^{-1}$ Fe NPs for $48 \mathrm{~h}$ enhanced hyoscyamine and scopolamine production (Table 1). All of the studies mentioned above confirm the possibility of NPs being employed as successful and promising bioactive compound elicitors in plant cell and organ cultures. Further studies are needed to evaluate the elicitation potential of various other NPs on secondary metabolite production in plant tissue cultures and the corresponding mechanisms.

\section{The toxicity concerns and safety issues surrounding exposure of plant tissue cultures to nanomaterials}

There is no doubt that nanomaterials hold diverse promise and have been proven to have outstanding potential. However, working with invisible components does become more challenging. Nanotoxicology is a flourishing branch which has evolved to record the negative aspects of nanomaterials. Because of quantum size effects and their large surface area to volume ratio, nanomaterials have unique properties compared to their larger counterparts; one such unique property is an added toxicological feature that nanomaterials may possess, unlike their corresponding bulk materials. Nanomaterials, even when made of inert elements like gold, become highly active at nanometer dimensions. Nanotoxicological studies determine whether and to what extent these properties may pose a threat to the environment and to human beings. There is an uncontrollable nano-boom that has brought about a wealth of positive changes, but simultaneously it is giving rise to a persistent form of pollution that is too small to detect or contain easily. Fighting a known enemy is much easier than fighting an invisible one. The health effects of nanopollution are yet to be fully understood, making nanopollution yet another man-made environmental disaster with uncertain long term effects in the making. Nanoparticles, being incredibly hard to isolate and quantify, require the invention of novel methods to fully assess the scale of the issue.

Thus far, the toxicity assessment of nanomaterials on plants has been mostly evaluated during in vitro seed germination and subsequent growth of seedlings. Researchers have elaborately reviewed the toxicity aspects of nanomaterials on plants. ${ }^{\mathbf{1 0 2}-106}$ They suggest that the nanomaterials added to the culture medium can lead to significant and adverse effects on cell viability, organogenesis, shoot growth, seed germination, seedling development and explant survival. The phytotoxicity of nanomaterials is believed to depend on their chemical composition, dose, size, stability and type, the composition of the culture medium, the application method, and the explant type and plant species. In vitro seed germination and seedling growth of Alfalfa, barley, maize, rice, tomato and wheat was reported to be negatively impacted by high doses of carbon nanomaterials and metal NPs. ${ }^{104,107}$ Addition of NPs to the cell suspension reduced the viability of the cells by altering nucleic acid expression, inducing DNA damage, increasing the production of ROS, disturbing chlorophyll synthesis, inducing cell membrane damage and inducing electrolyte leakage. ${ }^{63,64,100,105}$ To date, the uptake of NPs into plants has not been assessed or documented. Research reports record their findings based on the addition of a broad range of concentrations to the growth medium for investigating the phytotoxicity of various nanomaterials. It has been reported that the uptake of NPs by plant cell, tissue and organ cultures is closely associated with the absorption of moisture and nutrients from the medium. ${ }^{108,109}$

Most of these studies are restricted to in vitro conditions only; almost none or only a handful apply to in vivo studies. In vivo, laboratory or greenhouse conditions would completely differ from the field conditions; hence, more realistic and largescale assessment of the nanomaterial life cycle in field environments will give a holistic picture to the toxicity aspects of nanomaterials on plants. More stringent dose-dependent studies are needed to identify the ideally safe NP doses that stay within the positive impacts on plant growth with lesser 
negative impacts on the environment as well as plants. Thus, a series of safety evaluation and toxicological risk assessment standards should be formulated, including exposure route and safe exposure doses, ${ }^{\mathbf{1 0 7}}$ and meticulously applied for plant nanotechnology. The whole life cycle of these NPs should be evaluated, including their fabrication, storage and distribution, application and potential abuse, and disposal. Bioaccumulation, penetration, and translocation of NPs in plants should be evaluated in detail, specifically for individual NPs used, since each nanomaterial is unique and the results cannot be generalized. This being a cross-disciplinary area of research, appropriate awareness of the positive and negative aspects of nanoparticles is mandatory for the user.

\section{Future prospects of nano- integrated plant tissue culture}

From the disclosed reports citing the influence of NPs on plant tissue culture, there is no doubt that NPs have a lot to offer in terms of various aspects of plant biotechnology. Beginning from the first phase, through disinfection, to differentiation of the callus, genetic transformation, somaclonal variation and production of secondary metabolites, NPs have demonstrated their positive roles. Having set the stage, this is now just the tip of the iceberg; nanotechnology has more to offer, and it is time to explore and delve more into nano-resources and incorporate them into plant tissue culture. Nanotechnology is a multidisciplinary subject and offers limitless scope in multiple areas. For example, although a wide range of NPs have been reported to possess potent antimicrobial activity, only a few NPs, such as $\mathrm{Ag}, \mathrm{TiO}_{2}, \mathrm{Zn}$ and ZnO NPs, have been so far predominantly used for controlling microbial contaminants in plant tissue culture. With new-age materials like graphene, graphite, quantum dots, carbon nanotubes, polymer dendrimers and atomic clusters being developed, which all have established bactericidal and fungicidal activities, it is time to plunge deeper into these rich reservoirs of nanotechnology. Who knows? Maybe the best is yet undisclosed (Fig. 4)!

Furthermore, as explained in Section 3, the choke in the pipeline is that whilst using these nanomaterials freely in living systems, the nanotoxicity aspects need to be well contemplated and thought upon. Several studies have demonstrated that NP treatment can severely damage explants and adversely affect the regeneration potential of the explants. While the incorporation of NPs into the culture medium eliminates microbial contaminants and hence could be useful for germplasm conservation, their presence in the medium and their possible uptake by the plants needs to be monitored. The effects of NPs on callus induction, organogenesis, shoot multiplication, shoot elongation, and rooting are also not well documented. Additionally, the subculture effects on callus proliferation and shoot multiplication in the presence of NPs need to be studied in detail. Moreover, a few studies have shown that the presence of NPs in the culture medium causes somaclonal variation; therefore, long-term exposure of plant cultures to NPs may negatively affect morphogenesis too. The addition of NPs can lead to enhanced bioactive compound content in cell, shoot and root cultures, possibly due

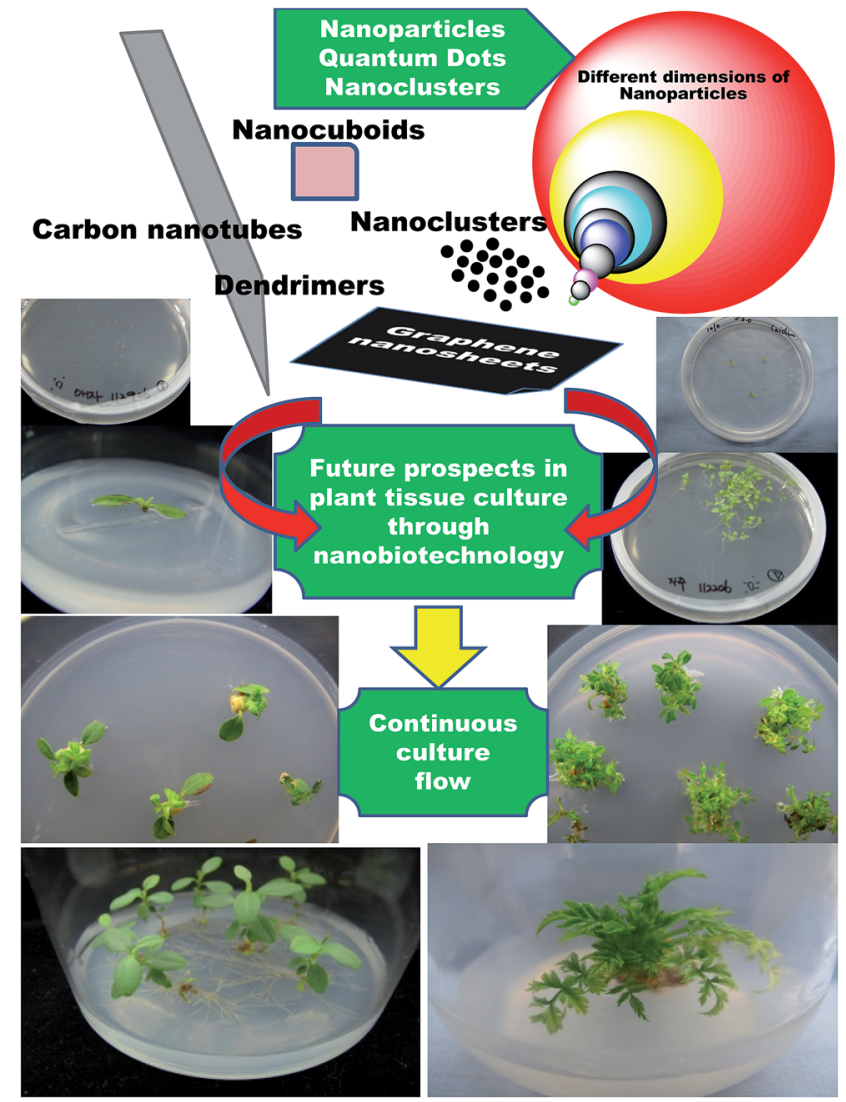

Fig. 4 Future prospects envisioned for nanotechnology in plant tissue culture to scale newer heights through suggested incorporation of new-age revolutionary nanomaterials.

to the production of ROS, activation of antioxidant enzymes and regulation of specific genes; however, the mechanism behind this is still unclear. The influence of various NPs on secondary metabolite production from several important plant species, and the chemical and physical properties and biological activities of compounds obtained from NP-treated plant cultures also need to be investigated in depth. The fate of NPs whilst interacting with plants needs to be fundamentally explored and transparent observations made and disclosed. Without this estimate, no real progress can be made without real time repercussions.

\section{Conclusion}

Even with all of these undisclosed facts looming in the backdrop as a shadow, there is still no question that plant nanobiotechnology is emerging as a prominent and promising field with excellent potential towards plant improvement. What is required is more targeted research to clarify and streamline the process to harness only the beneficial aspects without exposure to the adverse effects.

\section{Acknowledgements}

This article was supported by the KU Research Professor Program of Konkuk University. 


\section{References}

1 T. Thorpe, Mol. Biotechnol., 2007, 37, 169-180.

2 I. Sivanesan and S. W. Park, Ind. Crops Prod., 2015, 76, 323328.

3 K. Keren, R. S. Berman, E. Buchstab, U. Sivan and E. Braun, Science, 2003, 302, 1380-1382.

4 Q. A. Pankhurst, J. Connolly, S. K. Jones and J. Dobson, J. Phys. D: Appl. Phys., 2003, 36, R167-R181.

5 W. J. Parak, D. Gerion, T. Pellegrino, D. Zanchet, C. Micheel, S. C. Williams, R. Boudreau, M. A. Le Gros, C. A. Larabell and A. P. Alivisatos, Nanotechnology, 2003, 14, R15-R27.

6 H. Yan, S. H. Park, G. Finkelstein, J. Reif and T. LaBean, Science, 2003, 301, 1882-1884.

7 C. McGovern, Nanotechnol. Perceptions, 2010, 6, 158-178.

8 F. Dong, R. T. Koodali, H. Wang and W. K. Ho, J. Nanomater., 2014, 276467, DOI: 10.1155/2014/276467.

9 P. Kerativitayanan, J. K. Carrow and A. K. Gaharwar, $A d v$. Healthcare Mater., 2015, 4, 1600-1627.

10 P. Wang, E. Lombi, F. J. Zjao and P. M. Kopittke, Trends Plant Sci., 2016, 21, 1-12.

11 B. Ruttkay-Nedecky, O. Krystofova, L. Nejdl and V. Adam, J. Nanobiotechnol., 2017, 15, 33, DOI: 10.1186/s12951-0170268-3.

12 M. H. Siddiqui and M. H. Al-Whaibi, Saudi J. Biol. Sci., 2014, 21, 13-17.

13 M. Delfani, M. B. Firouzabadi, N. Farrokhi and H. Makarian, Commun. Soil Sci. Plant Anal., 2014, 45, 530540.

14 F. Torney, B. G. Trewyn, V. S. Lin and K. Wang, Nat. Nanotechnol., 2007, 2, 295-300.

15 H. Oloumi, R. Soltaninejad and A. Baghizadeh, Indian J. Plant Physiol., 2015, 20, 157-161.

16 H. J. Park, S. H. Kim, H. J. Kim and S. H. Choi, Plant Pathol. J., 2006, 22, 295.

17 M. K. Sarmast and H. Salehi, Mol. Biotechnol., 2016, 58, 441449.

18 C. Leifert, C. E. Morris and W. M. Waites, Crit. Rev. Plant Sci., 1994, 13, 139-183.

19 C. Leifert and A. C. Cassells, In Vitro Cell. Dev. Biol.: Plant, 2001, 37, 133-138.

20 C. Leifert, H. Cammota and W. M. Waites, Plant Cell, Tissue Organ Cult., 1992, 29, 153-160.

21 G. A. Teixeira da Silva, T. Duong, T. Michi and F. Seiichi, Sci. Hortic., 2003, 97, 397-410.

22 Y. H. Qin, J. A. T. da Silva, J. H. Bi, S. L. Zhang and G. B. Hu, Plant Growth Regul., 2011, 65, 183-193.

23 E. V. Tambarussi, M. Rogalski, F. T. S. Nogueira, G. E. Brondani, V. F. De Martin and H. Carrer, Ann. Forest Res., 2015, 58, 177-183.

24 L. Wang, C. Hu and L. Shao, Int. J. Nanomed., 2017, 12, 1227-1249.

25 N. Beyth, Y. Houri-Haddad, A. Domb, W. Khan and R. Hazan, Evid. base. Compl. Alternative Med., 2015, 246012, DOI: 10.1155/2015/246012.
26 G. H. Abdi, H. Salehiand and M. Khosh-Khui, Acta Physiol. Plant., 2008, 30, 709-714.

27 M. Fakhrfeshani, A. Bagheri and A. Sharifi, Journal of Biological \& Environmental Sciences, 2012, 6, 121-127.

28 A. Gouran, M. Jirani, A. A. Mozafari, M. K. Saba, N. Ghaderi and S. Zaheri, Effect of silver nanoparticles on grapevine leaf explants sterilization at in vitro conditions, 2nd National Conference on Nanotechnology from Theory to Application, Isfahan, Iran, 20 February 2014, pp. 1-6.

29 N. Mahna, S. Z. Vahed and S. Khani, J. Nanomed. Nanotechnol., 2013, 4, 161, DOI: 10.4172/21577439.1000161.

30 A. A. Rostami and A. Shahsavar, Asian J. Plant Sci., 2009, 8, 505-509.

31 M. K. Sarmast, H. Salehi and M. Khosh-Khui, Acta Biol. Hung., 2011, 62, 477-484.

32 M. Arab, M. Yadollahi, A. Hosseini-Mazinani and S. Bagheri, J. Genet. Eng. Biotechnol., 2014, 12, 103-110.

33 T. Murashige and F. Skoog, Physiol. Plant., 1962, 15, 473497.

34 K. Safavi, M. Esfahanizadeh, D. H. Mortazaeinezahad and H. Dastjerd, The study of nano silver (NS) antimicrobial activity and evaluation of using NS in tissue culture media. Int Conf Life Sci Technol IPCBEE, IACSIT Press, Singapore, 2011, vol. 3, pp. 159-161.

35 K. Safavi, F. Mortazaeinezahad, M. Esfahanizadeh and M. J. Asgari, World Acad. Sci. Eng. Technol., 2011, 55, 372373.

36 K. Safavi, Evaluation of using nanomaterial in tissue culture media and biological activity, $2^{\text {nd }}$ International Conference on Ecological, Environmental and Biological Sciences (EEBS'2012), Bali, Indonesia, 13-14 October 2012, pp. 5-8.

37 K. Safavi, Bull. Environ., Pharmacol. Life Sci., 2014, 3, 163166.

38 S. Shokri, A. Babaei, M. Ahmadian, S. Hessami and M. M. Arab, International Journal of Farming and Allied Sciences, 2014, 3, 50-54.

39 P. Kalsaitkar, J. Tanna, A. Kumbhare, S. Akre, C. Warade and N. Gandhare, Asian J. Biol. Life Sci., 2014, 3, 167-172.

40 M. Mandeh, M. Omidi and M. Rahaie, Biol. Trace Elem. Res., 2012, 150, 376-380.

41 M. N. Helaly, M. A. El-Metwally, H. El-Hoseiny, S. A. Omar and N. I. El-Sheery, Aust. J. Crop Sci., 2014, 8, 612-624.

42 M. Taghizadeh and M. Solgi, J. Hortic. Sci. Technol., 2014, 1, 131-140.

43 J. L. Spinoso-Castillo, R. A. Chavez-Santoscoy, N. Bogdanchikova, J. A. Pérez-Sato, V. Morales-Ramos and J. J. Bello-Bello, Plant Cell, Tissue Organ Cult., 2017, 129, 195-207.

44 P. C. Maness, D. M. Smolinski, Z. Blake, E. J. W. Huang and W. A. Jacoby, Appl. Environ. Microbiol., 1999, 65, 4094-4098.

45 M. Heinlaan, A. Ivask, I. Blinova, H. C. Dubourguier and A. Kahru, Chemosphere, 2008, 71, 1308-1316.

46 Y. W. Baek and Y. J. An, Sci. Total Environ., 2011, 409, 16031608. 
47 S. J. Soenen, P. Rivera-Gil, J. M. Montenegro, W. J. Parak, S. C. De Smedt and K. Braeckmans, Nano Today, 2011, 6, 446-465.

48 G. Applerot, J. Lellouche, N. Perkas, Y. Nitzan, A. Gedanken and E. Banin, RSC Adv., 2012, 2, 2314-2321.

49 M. Guzman, J. Dille and S. Godet, Nanomedicine, 2012, 8, 37-45.

50 A. M. Allahverdiyev, E. S. Abamor, M. Bagirova and M. Rafailovich, Future Microbiol., 2011, 6, 933-940.

51 M. Aghdaei, H. Salehi and M. K. Sarmast, Adv. Hortic. Sci., 2012, 26, 21-24.

52 M. K. Sarmast, A. Niazi, H. Salehi and A. Abolimoghadam, Plant Cell, Tissue Organ Cult., 2015, 121, 227-236.

53 P. Sharma, D. Bhatt, M. G. H. Zaidi, P. P. Saradhi, P. K. Khanna and S. Arora, Appl. Biochem. Biotechnol., 2012, 167, 2225-2233.

54 H. Zafar, A. Ali, J. S. Ali, I. U. Haq and M. Zia, Front. Plant Sci., 2016, 7, 535, DOI: 10.3389/fpls.2016.00535.

55 V. Kumar, P. Guleria, V. Kumar and S. K. Yadav, Sci. Total Environ., 2013, 46, 462-468.

56 E. A. Genady, E. A. Qaid and A. H. Fahmy, Int. J. Pharm. Res. Allied Sci., 2016, 5, 196-202.

57 T. E. Talankova-Sereda, K. V. Liapina, E. A. Shkopinskij, A. I. Ustinov, A. V. Kovalyova, P. G. Dulnev and N. I. Kucenko, Nanosci. Nanoeng., 2016, 4, 31-39.

58 R. Javed, M. Usman, B. Yücesan, M. Zia and E. Gürel, Plant Physiol. Biochem., 2017, 110, 94-99.

59 H. F. Alharby, E. M. R. Metwali, M. P. Fuller and Y. A. Aldhebiani, Arch. Biol. Sci., 2016, 68, 723-735.

60 E. A. Ewais, S. A. Desouky and E. H. Elshazly, Nanosci. Nanotechnol., 2015, 5, 45-56.

61 M. Ghorbanpour and J. Hadian, Carbon, 2015, 94, 749-759.

62 M. V. Khodakovskaya, K. de Silva, A. S. Biris, E. Dervishi and H. Villagarcia, ACS Nano, 2012, 6, 2128-2135.

63 C. Lin, B. Fugetsu, Y. Su and F. Watari, J. Hazard. Mater., 2009, 170, 578-583.

64 X. M. Tan, C. Lin and B. Fugetsu, Carbon, 2009, 47, 34793487.

65 I. Kokina, E. Sïedevskis, V. Gerbreders, D. Grauda, M. Jermaïonoka, K. Valaine, I. Gavarâne, I. Pigiòka, M. Filipoviès and I. Rashal, Proc. Latv. Acad. Sci., Sect. B, 2012, 66, 200-209.

66 Y. Syu, J. H. Hung, J. C. Chen and H. Chuang, Plant Physiol. Biochem., 2014, 83, 57-64.

67 Z. Poborilova, R. Opatrilova and P. Babula, Environ. Exp. Bot., 2013, 91, 1-11.

68 C. Ma, S. Chhikara, B. Xing, C. Musante, J. C. White and O. P. Dhankher, ACS Sustainable Chem. Eng., 2013, 1, 768778.

69 C. Ma, H. Liu, H. Guo, C. Musante, S. H. Coskun, B. C. Nelson, J. C. White, B. Xing and O. M. Dhankher, Environ. Sci.: Nano, 2016, 3, 1369-1379, DOI: 10.1039/ c6en00189k.

70 S. Anwaar, Q. Maqbool, N. Jabeen, M. Nazar, F. Abbas, B. Nawaz, T. Hussain and S. Z. Hussain, Front. Plant Sci., 2016, 7, 1330, DOI: 10.3389/fpls.2016.01330.
71 L. Giorgetti, M. M. Castiglione, M. Bernabini and C. Geri, Agrochimica, 2011, 55, 45-53.

72 I. Kokina, V. Gerbreders, E. Sledevskis and A. Bulanovs, J. Biotechnol., 2013, 165, 127-132.

73 H. Fazal, B. H. Abbasi, N. Ahmad and M. Ali, Appl. Biochem. Biotechnol., 2016, 180, 1076-1092.

74 S. Bansod, M. Bawskar and M. Rai, IET Nanobiotechnol., 2015, 9, 239-245.

75 P. S. Vijayakumar, O. U. Abhilash, B. M. Khan and B. L. V. Prasad, Adv. Funct. Mater., 2010, 20, 2416-2423.

76 K. Pasupathy, S. Lin, Q. Hu, H. Luo and P. C. Ke, Biotechnol. J., 2008, 3, 1078-1082.

77 S. Naqvi, A. N. Maitra, M. Z. Abdin, M. Akmal, I. Arors and M. Samim, J. Mater. Chem., 2012, 22, 3500-3507.

78 M. R. S. Ardekani, M. Z. Abdeni, N. Nasrullaah and M. Samim, Int. J. Pharm. Sci., 2014, 6, 605-609.

79 F. P. Chang, L. Y. Kuang, C. A. Huang, W. N. Jane, Y. Hung, Y. C. Hsing and C. Y. Mou, J. Mater. Chem. B, 2013, 1, 52795287.

80 Y. Hao, X. Yang, Y. Shi, S. Song, J. Xing, J. Marowitch, J. Chen and J. Chen, Botany, 2013, 91, 457-466.

81 M. W. Bairu, A. O. Aremu and J. Van Staden, Plant Growth Regul., 2011, 63, 147-173.

82 I. Sivanesan and B. R. Jeong, Plant Cell, Tissue Organ Cult., 2012, 111, 247-253.

83 B. R. Jeong and I. Sivanesan, Plant Cell, Tissue Organ Cult., 2015, 123, 607-618.

84 D. H. Atha, H. Wang, E. J. Petersen, D. Cleveland, R. D. Holbrook, P. Jaruga, M. Dizdaroglu, B. Xing and B. C. Nelson, Environ. Sci. Technol., 2012, 46, 1819-1827.

85 P. Landa, S. Prerostova, S. Petrova, V. Knirsch, R. Vankova and T. Vanek, Environ. Sci. Technol., 2015, 49, 14537-14545.

86 D. K. Tripathi, S. Shweta, S. Singh, R. Pandey, V. P. Singh, N. C. Sharma, S. M. Prasad, N. K. Dubey and D. K. Chauhan, Plant Physiol. Biochem., 2017, 110, 2-12.

87 I. Kokina, I. Mickevica, M. Jermalonoka, L. Bankovska, V. Gerbreders, A. Ogurcovs and I. Jahundovica, Int. J. Genomics, 2017, 1676874, DOI: 10.1155/2017/1676874.

88 M. Hussain, S. Fareed, S. Ansari, M. Rahman, I. Z. Ahmad and M. Saeed, J. Pharm. BioAllied Sci., 2012, 4, 10-20.

89 I. Sivanesan, R. K. Saini and D. H. Kim, Ind. Crops Prod., 2016, 83, 31-38.

90 I. Sivanesan, R. K. Saini, R. Noorzai, A. J. Zamany and D. H. Kim, 3 Biotech., 2016, 6, 91.

91 H. K. Mohammed Al-oubaidi and A. S. Mohammed-Ameen, Int. J. Pharmacol. Ther., 2014, 5, 267-272.

92 H. K. Mohammed Al-oubaidi and N. M. Kasid, World J. Pharm. Res., 2015, 4, 1791-1799.

93 E. Chamani, S. K. Ghalehtaki, M. Mohebodini and A. Ghanbari, Iranian Journal of Genetics and Plant Breeding, 2015, 4, 11-19.

94 C. V. Desai, H. B. Desai, K. P. Suthar, D. Singh, R. M. Patel and A. Taslim, Appl. Biol. Res., 2015, 17, 1-7.

95 B. Zhang, L. P. Zheng, W. Y. Li and J. W. Wang, Curr. Nanosci., 2013, 9, 363-370.

96 B. Ghasemi, R. Hosseini and F. D. Nayeri, Turk. J. Bot., 2015, 39, 769-777. 
97 Z. Shakeran, M. Keyhanfar, G. Asghari and M. Ghanadian, Turk. J. Biol., 2015, 39, 111-118.

98 M. Raei, S. A. Angaji, M. Omidi and M. Khodayari, Int. J. Biosci., 2014, 5, 74-81.

99 P. Bhat and A. Bhat, J. Exp. Sci., 2016, 7, 1-6.

100 M. Jamshidi, F. Ghanati, A. Rezaei and E. Bemani, Cytotechnology, 2016, 68, 525-530.

101 F. Moharrami, B. Hosseini, A. Sharafi and M. Farjaminezhad, In Vitro Cell. Dev. Biol.: Plant, 2017, 53, 104-111.

102 P. Miralles, L. T. Church and A. T. Harris, Environ. Sci. Technol., 2012, 46, 9224-9239.

103 G. Chichiriccò and A. Poma, Nanomaterials, 2015, 5, 851873, DOI: $10.3390 /$ nano5020851.

104 O. Zaytseva and G. Neumann, Chem. Biol. Technol. Agric., 2016, 3, 17, DOI: 10.1186/s40538-016-0070-8.
105 J. Yang, W. Cao and Y. Rui, J. Plant Interact., 2017, 12(1), 158-169.

106 S. Mishra, C. Keswani, P. C. Abhilash, L. F. Fraceto and H. B. Singh, Front. Plant Sci., 2017, 8, 471, DOI: 10.3389/ fpls.2017.00471.

107 B. Ruttkay-Nedecky, O. Krystofova, L. Nejdl and V. Adam, J. Nanobiotechnol., 2017, 15, 33, DOI: 10.1186/s12951-0170268-3.

108 C. W. Lee, S. Mahendra, K. Zodrow, D. Li, Y.-C. Tsai, J. Braam and P. J. J. Alvarez, Environ. Toxicol. Chem., 2010, 29, 669-675.

109 S. Lin, J. Reppert, Q. Hu, J. S. Hudson, M. L. Reid, T. A. Ratnikova, A. M. Rao, H. Luo and P. C. Ke, Small, 2009, 5, 1128-1132. 